\title{
OCHRONA

\section{ADAPTACJA LABORATORIUM MASZYNOWEGO DAWNEJ SZKOłY RZEMIOSŁ BUDOWLANYCH I WYŻSZEJ SZKOŁY BUDOWY MASZYN NA BIBLIOTEKĘ WYDZIAŁU ARCHITEKTURY POLITECHNIKI WROCŁAWSKIEJ}

\section{GRODZKA Elżbieta ${ }^{1}$}

1 dr inż. arch. Elżbieta M. Grodzka, Wydział Architektury Politechniki Wrocławskiej, Zakład Konserwacji i Rewaloryzacji Architektury i Zieleni

https://orcid.org/0000-0002-1150-252X

ABSTRAKT: Budynek laboratorium maszyn powstał w latach w 1905-1907, jako ostatni element kompleksu dawnej Szkoły Rzemiosł Budowlanych na wrocławskim Ołbinie. Obiekt został dość mocno zniszczony w trakcie II wojny światowej. W latach 60 . XX w. zachowane resztki budowli zostały, w sposób dość prowizoryczny, odbudowane i zaadaptowane na warsztat mechaniki precyzyjnej dla Politechniki Wrocławskiej. Na początku XXI w. rozpoczęto działania rewitalizacyjne mające na celu przekształcenie zabytkowego kompleksu w nowoczesny kampus edukacyjny. Budynek dawnego laboratorium maszynowego przeznaczono do odbudowy i adaptacji na bibliotekę Wydziału Architektury Politechniki Wrocławskiej. Projekt został poprzedzony badaniami i analizami historycznymi. Prace przeprowadzono w latach 2014-2017.

SŁOWA KLUCZE: Wydział Architektury, adaptacja, Karl Klimm, Szkoła Rzemiosł Budowlanych 


\section{Wstęp}

Polska tradycja Wydziału Architektury na Politechnice Wrocławskiej została zbudowana w większości przez kadrę naukową przybyłą ze Lwowa po zakończeniu II wojny światowej, $\mathrm{w}$ ramach przymusowych repatriacji. Odradzająca się uczelnia przejęła zaplecze lokalowe i techniczne po dawnej Technische Hochschule. Do 1968 r. Wydział Architektury zajmował część budynku przy Wybrzeżu Wyspiańskiego 27, kiedy to został przeniesiony do jednego z obiektów przy ul. Bolesława Prusa 53-55, należącego przed wojną do Szkoły Rzemiosła Budowlanego i Wyższej Szkoły Budowy Maszyn (Baugewerk- und Maschinenbauschule). Początkowo Wydział zajmował budynek główny, wspólnie z Wydziałem Elektroniki. Na początku XXI w. Politechnika Wrocławska pozyskała całość terenu, wraz z innymi obiektami należącymi niegdyś do Szkoły. Od 2007 r. trwają intensywne działania rewitalizacyjne zmierzające do utworzenia współczesnego kampusu edukacyjnego, kształcącego przyszłych architektów ${ }^{1}$. Jednym $z$ jej etapów były przeprowadzone w latach 2011-2016 prace przy dawnym budynku laboratorium maszyn zmierzające do adaptacji na bibliotekę.

\section{Rys historyczny}

Szkoła Rzemiosła Budowlanego i Wyższa Szkoła Budowy Maszyn została zbudowana w latach 1902-1907 w kwartale wyznaczonym przez ulice Chemiczną, B. Prusa, Ł. Górnickiego oraz Rozbrat według projektu Karla Klimma, realizującego koncepcję Richarda Plüddemanna aby budynki nowej szkoły stanowiły równocześnie pomoc dydaktyczną dla słuchaczy ${ }^{2}$. W skład kompleksu wchodziły: budynek główny, usytuowany w północno-zachodniej części działki, parterowy budynek sanitariatów (rozebrany po 1945 r.), willa dyrektora oraz laboratorium budowy maszyn.

Ze względu na wielkość inwestycji, prace prowadzono etapami. Laboratorium budowy maszyn było ostatnim, zrealizowanym w latach 1905-1907, obiektem Szkoły. Początkowo rozważano możliwość połączenia go $\mathrm{z}$ budynkiem głównym ${ }^{3} \mathrm{w}$ jego południowo-wschodnim narożniku. Ostatecznie laboratorium zostało zbudowane jako wolnostojący obiekt w południowej części działki na zamknięciu osi widokowej dzisiejszej ul. Ukrytej (d. Fiedlerstrasse).

\footnotetext{
Teren zajmowany przed II wojną światową przez Szkołę Rzemiosł Budowlanych i Wyższą Szkołę Budowy Maszyn został podzielony pod koniec lat 40. XX w. pomiędzy Politechnikę Wrocławską i Uniwersytet Przyrodniczy (wówczas Wydział Rolniczy Uniwersytetu Wrocławskiego, przekształcony w latach późniejszych w osobną uczelnię). Od tego czasu na tym obszarze miały miejsce przekształcenia o charakterze utylitarnym, dające niekorzystny efekt urbanistyczny i architektoniczny, jak budowa w latach 70. XX w. dwóch tzw. pawilonów namysłowskich. Na początku XXI w. doszło do scalenia własnościowego obszaru dawnej Szkoły, co dało początek rewitalizacji całego kompleksu, oraz w $2010 \mathrm{r}$. wyburzono pawilony.

2 Por. Gryglewska A., Architektura Wrocławia XIX-XX wieku w twórczości Richarda Plüddemanna, Oficyna Wydawnicza Politechniki Wrocławskiej, Wrocław 1999, s. 160-161.

3 Projekt zagospodarowania terenu z 1902 r., Archiwum Budowlane m. Wrocławia, syg. 2159.
} 
W budynku znajdowały się różne strefy funkcjonalne, wyodrębnione nie tylko w planie, ale również w bryle, poprzez zróżnicowaną wysokość, rodzaj dachu, typ stolarki ${ }^{4}$. Od południa, $\mathrm{w}$ parterze znajdowała się pompownia $\mathrm{z}$ wieżą wodną, powyżej - na poddaszu krytym dwuspadowym dachem $\mathrm{z}$ murowanymi lukarnami, mieściło się mieszkanie mechanika. Północne skrzydło zajmowała jednokondygnacyjna hala maszyn, przeznaczona do zajęć dydaktycznych, $\mathrm{z}$ wielospadowym dachem. Po stronie wschodniej znajdowały się dwa parterowe ryzality mieszczące halę obrabiarek oraz kotłownię parową, opalaną węglem. Obie części zostały przykryte dachem pulpitowym. W sąsiedztwie kotłowni umieszczono dość wysoki komin spalinowy. Okna w halach oraz pomieszczeniach technicznych były żelazne o dość dużej powierzchni. W części mieszkalnej zastosowano stolarkę drewnianą.

W budynku laboratorium maszyn zastosowano takie same materiały wykończeniowe zewnętrzne jak w przypadku innych obiektów wchodzących w skład zespołu. Elewacje były tynkowane ${ }^{5}$, z elementami wykonanymi z piaskowca takimi jak cokół w południowo-zachodnim narożniku, nadproża, parapety i krawędzie szczytów. Od południa znajdowało się wejście do mieszkania mechanika, ujęte w gotycki portal ${ }^{6}$. Dachy pokrywała dachówka karpiówka. Dekoracja rzeźbiarska nie była w przypadku budynku laboratorium maszyn tak bogata, jak np. w budynku głównym czy willi dyrektorów i ograniczała się do litery „W” (symbolizującej Wrocław łac. Wratislavia) oraz „Erbaut 1905” (data rozpoczęcia budowy)7. Obiekt przyłączony był do miejskich sieci wodociągowych, kanalizacyjnych oraz elektrycznych.

W czasie I wojny światowej budynki Szkoły zostały przekazane na potrzeby armii. Po zakończeniu działań wojennych obiekty musiały zostać wyremontowane.

W halach laboratorium odbywały się zajęcia przede wszystkich dla słuchaczy Szkoły Budowy Maszyn. We wnętrzach znajdowały się takie maszyny jak tokarki, frezarki czy obrabiarki, przy których uczniowie wykonywali ćwiczenia pod okiem nauczyciela. Zewnętrze obiektu służyło za pomoc dydaktyczną dla słuchaczy Szkoły Rzemiosł Budowlanych, poprzez m.in. ekspozycję różnych sposobów wykonywania kamiennego boniowania na fragmencie elewacji przy wieży wodnej.

\footnotetext{
Szczegółowe studium historyczne wraz z wykazem zachowanych materiałów archiwalnych, obejmujące lata 1902-2009 dla budynku głównego, willi dyrektorów, nieistniejącego sanitariatu oraz laboratorium maszynowego zostało wykonane przez Agnieszkę Gryglewską i Wojciecha Brzezowskiego w 2009 r. Powyższy opis historii obiektu bazuje na tym opracowaniu, Por. Gryglewska A., Brzezowski W., Studium historyczne z wnioskami konserwatorskimi komplesku dawnej Baugewerk und Maschinenbauschule, obecnie budynków Politechniki Wrocławskiej przy ul. B. Prusa 53/55 we Wrocławiu, Sprawozdanie z serii nr 029/09, rękopis, Wrocław 2009.

5 Tynk posiadał żłobienia poziome. Cokoły w pozostałej części budynku były ceglane.

6 Portal pochodził prawdopodobnie z jednej z wrocławskich zburzonych w tym czasie kamienic, Gryglewska A., Brzezowski W., op cit s. 74 .

7 Pozostałe budynki kompleksu Szkoły Rzemiosł Budowlanych i Wyższej Szkoły Budowy Maszyn posiadały znacznie bogatsze zdobienia rzeźbiarskie, nawiązujące do motywów roślinnych oraz ornamentów alegorycznych związanych z rzemiosłem.
} 


\section{Zniszczenie obiektu w $1945 \mathrm{r}$. i powojenna odbudowa}

W trakcie II wojny światowej obiekty były wykorzystywane przez wojsko, m.in. w budynku głównym urządzono szpital polowy. Podczas oblężenia Festung Breslau, prawdopodobnie między 11 a 15 marca, na skutek bombardowań Ołbina, została zniszczona hala maszyn oraz kotłownia $\mathrm{z}$ kominem $^{8}$. Po II wojnie światowej obiekty zostały podzielone pomiędzy różne instytucje państwowe: Uniwersytet Wrocławski, Politechnikę Wrocławską oraz Uniwersytet Przyrodniczy (dawną Akademię Rolniczą). Budynek dawnego laboratorium maszyn, zniszczony w 75\%, przeszedł pod zarząd Politechniki ${ }^{9}$.

W 1963 r. rozpoczęto prace adaptacyjne zachowanych resztek obiektu na warsztat mechaniki precyzyjnej wg opracowania Czesława Oleksego ${ }^{10}$. Obiekt nie był wówczas objęty żadną ochroną konserwatorską ${ }^{11}$, a projekt nie został poprzedzony studiami i badaniami nad jego wartością historyczną. Planowane zabiegi adaptacyjne miały charakter wyłącznie utylitarny i zostały przeprowadzone jak najtańszymi metodami wykonawstwa budowlanego.

Rozebrano fragmenty budowli,którebyły w złym stanietechnicznym, jak resztki więźby dachowej czy mury powyżej poziomu parteru wraz z wieżą wodną. We wnętrzu dokonano licznych przemurowań, m.in. zmniejszenia istniejących otworów okiennych oraz układu otworów drzwiowych. Z jednoprzestrzennego wnętrza dawnej pompowni wydzielono pomieszczenie do obróbki ręcznej, kolejne do obróbki wtórnej oraz węzeł sanitarny. Zachowano natomiast strop typu Koenen, wsparty na środku pomieszczenia żelazną kolumną. Hala obrabiarek (po stronie wschodniej) została przekształcona na zaplecze magazynowe, wraz z malarnią i galwanizatorią. Nad parterem pompowni nadbudowano jedną kondygnację z przeznaczeniem na laboratorium pomiarowe, salę montażową, pracownię techniczną, magazyny i mały węzeł sanitarny.

Bryła została bardzo mocno uproszczona. Nadbudowane piętro przykryto stropodachem o konstrukcji DZ3 o niewielkim spadku rzędu 5\%, krytym papą na lepiku. Nad halą obrabiarek zachowano istniejący strop odcinkowy na belkach stalowych oraz drewnianą więźbę dachową, stanowiącą konstrukcję dachu pulpitowego. Wymieniono stolarkę oraz wykonano nowe schody o konstrukcji stalowej. Elewacja została otynkowana z zachowaniem ceglanego cokołu i kamiennego boniowania w południowo-zachodnim narożniku. Pozostawiono płaskorzeźbę z literą „W”, natomiast niemiecki napis „Erbaut 1905” - zatynkowano.

Pod koniec lat 70. XX w. rozważano modernizację lub ewentualną rozbudowę lub nadbudowę obiektu, jednak ze względu na ograniczenia techniczne istniejącej struktury oraz konieczność

8 Gryglewska A., Brzezowski W., op cit s. 33.

9 Gryglewska A., Gmach dawnej Szkoły Rzemiosł Budowlanych - siedziba Wydziału Architektury Politechniki Wrocławskiej. Idea projektu [w:] Schola Architecturae Budynki Szkół Architektury, red. O. Czerner, A. Gryglewska, Oficyna Wydawnicza Politechniki Wrocławskiej, Wrocław 2005, s. 89.

10 Projekt techniczno-roboczy - warsztat mechaniki precyzyjnej, proj. Czesław Oleksy, ul. Chemiczna 4, Wrocław 1963, Archiwum Działu Infrastruktury Technicznej Pwr (ADITPwr), syg ACT/AR-E3/1, poz. 1, 3.

11 W latach 60. XX w. za zabytki nie były uznawane obiekty pochodzące z XIX i pocz. XX w. zbudowane w stylu historyzyjącym lub secesji. 
poniesienia sporych nakładów inwestycyjnych, pomysłu tego nie zrealizowano ${ }^{12}$. Budynek pełnił funkcje warsztatu do ok. 1980 r., w 1981 był obiektem gospodarczym, a w latach 90. XX w. do 2006 r. - pawilonem warsztatowym dla Instytutu Metrologii oraz Telekomunikacji i Akustyki Wydziału Elektroniki PWr.

\section{Założenia konserwatorskie do odbudowy i adaptacji budynku na bibliotekę wydziałową}

Materiałem wyjściowym dla prac nad projektem przebudowy i adaptacji resztek dawnego laboratorium maszynowego na bibliotekę dla Wydziału Architektury Politechniki Wrocławskiej stanowiło opracowanie wykonane w 2009 r. przez Agnieszkę Gryglewską i Wojciecha Brzezowskiego. Zawierało ono wnikliwe studia historyczne całego dawnego kompleksu Szkoły oraz wnioski i wytyczne konserwatorskie ${ }^{13}$. Przeprowadzone $\mathrm{w}$ tym opracowaniu studia nad wartością historyczną dawnego laboratorium zaowocowały wpisem zachowanych resztek budowli do ewidencji zabytków miasta Wrocławia. W wyniku badań, autorzy studium stwierdzili, iż szczątkowy stan zachowania autentycznej substancji, pozbawionej pierwotnej funkcji nie daje podstaw do kategorycznego wymogu zachowania, a tym bardziej do rekonstrukcji pierwotnego budynku, choć stanowił on ważny element kompozycyjny zespołu ${ }^{14}$. W rezultacie głównym problemem projektowym stało się zestawienie zachowanych reliktów budowli z nową częścią $\mathrm{w}$ taki sposób, aby całość stworzyła harmonijny obraz z pozostałymi budynkami dawnego kampusu.

\section{Realizacja - zastosowane zabiegi konserwatorskie i adaptacja do współczesnych wymagań użytkowych}

Projekt koncepcyjny przekształcenia obiektu w nowoczesną bibliotekę uniwersytecką powstał w 2011 r. w pracowni Creoprojekt $z$ Wrocławia ${ }^{15}$. Głównym założeniem autorów było odtworzenie oryginalnej bryly budynku wraz $z$ wieżyczka $i$ wplecenie w nia nowej funkcji ${ }^{16}$. Efektem prac była koncepcja urządzenia nowych pomieszczeń dydaktycznych wraz z niezbędnym zapleczem magazynowym oraz archiwum, ubranych we współczesną interpretację tradycyjnych wzorców architektury ${ }^{17}$.

\footnotetext{
12 Protokół nr 14/78 z posiedzenia Rady Naukowo-Technicznej z dn. 21.06.1978 w Zakładzie StudyjnoProjektowym Politechniki Wrocławskiej, ADITPwr, syg ACT/AR-E3/2, poz. 2.

13 Por. Gryglewska A., Brzezowski W., op cit.

14 Gryglewska A., Brzezowski W., op cit s. 106.

15 Projekt koncepcyjny nadbudowy wraz z przebudową i zmianą sposobu użytkowania budynku dawnego laboratorium E3 na budynek biblioteki Wydziału Architektury Politechniki Wrocławskiej przy ul. Chemicznej 4 we Wrocławiu, proj. Bartosz M. Żmuda, Wrocław, marzec 2011, ADITPwr, syg ACT/AR-E3/5, poz. 1.

16 Wypowiedź z fanpage biura, https://www.facebook.com/biurocreoproject [dostęp: 29.01.2019].

$17 \mathrm{~W}$ początkowych etapach projektu koncepcyjnego rozważano różne koncepcje kształtowania bryły budynku, od całkowitego odejścia od formy historycznej i zachowanie formy z lat 60. XX w., aż po wierną rekonstrukcję obiektu w formie sprzed 1945 r. Akceptację zarówno przez Inwestora jak i Konserwatora Zabytków m. Wrocławia zyskała wersja częściowo historyzująca. - na pods. wywiadu przeprowadzonego przez autorkę z jednym z projektantów B. Szczepańskim dn. 21 lipca 2020.
} 
Istniejące piwnice przewidziano do zasypania ${ }^{18}$. Całość założonego programu użytkowego miała pomieścić część nadziemna budynku: dawna pompownia o przybliżonych wymiarach 13x15m wraz z halą obrabiarek 7,7x11m. Główną część magazynową wraz z wypożyczalnią, oraz miejscem pracy przystosowanym dla osoby niepełnosprawnej ulokowano na parterze. Charakter jednoprzestrzennej hali nie został jednak przywrócony, ponieważ wydzielono przedsionek przy wejściu głównym dla czytelników od zachodu, oraz oddzielono częściowo strefę magazynową od wypożyczalni. Zdemontowano schody z lat 60 . XX w., prowadzące na antresolę. Pozostawiono klatkę schodową od strony południowej, zwiększono natomiast ilość biegów tak, aby prowadziły na wieżę. W przestrzeni na parterze, pod spocznikiem schodów, zaprojektowano toaletę przeznaczoną dla osób niepełnosprawnych. Zaplecze mieszczące biura, węzeł cieplny, pomieszczenia socjalne oraz wejście dla pracowników biblioteki zlokalizowano w dawnej hali obrabiarek. Na piętrze zaprojektowano czytelnię wraz z niezbędnym zapleczem sanitarnym, połączoną z tarasem na dachu dawnej hali obrabiarek. W toku eksploatacji okazało się, że przewidziana w projekcie powierzchnia magazynowa nie jest wystarczająca. Konieczne stało się dostawienie dodatkowych regałów magazynowych w czytelni, zmniejszając nieco jej powierzchnię.

Przyjęty program konserwatorski obejmował konserwację i ekspozycję reliktów murów parteru, zwłaszcza południowo-zachodniego narożnika $\mathrm{z}$ kamiennym boniowaniem i zachowanym reliefem litery „W”. W trakcie prac odkryto również napis „Ergebaut 1905”, który odsłonięto i zakonserwowano. Podobnie postąpiono ze ścianę południową z zachowanym gotyckim portalem.

W sposobie kształtowania formy obiektu zdecydowano się na częściową reintegrację pierwotnej bryły. Nie zdecydowano o odtworzeniu bryły hali maszyn oraz kotłowni, zniszczonych w 1945 r., natomiast odtworzono wieżę wodną o wysokości $17,75 \mathrm{~m}$, jako ważny element zamykający oś kompozycyjną ul. Ukrytej. Przywrócono dwuspadowy dach nad dawną pompownią, o nachyleniu połaci $45^{\circ}$ wraz z lukarnami doświetlającymi czytelnię $e^{19}$.

Elewacje ukształtowano odmienne w zależności od stopnia zachowania ich oryginalnego detalu. Na zewnętrznej ścianie południowej, mieszczącej gotycki portal oraz kamienne boniowanie, odtworzono kamienną dekorację szczytu. Zastosowano podobne do pierwotnych materiały i technologie budowlane, jak tynk ryflowany grzebieniem o zębach skośnych (o nierównych kątach, drewnianą, stylizowaną stolarkę okienną, wykonaną wg współczesnych standardów, ale o podziałach historycznych). Przewrócono pierwotny kształt i wielkość otworów okiennych.

18 „Piwnica znajdowała się jedynie pod częścią budynku bez dostępu wewnętrznymi schodami. Była w bardzo złym stanie technicznym, wysokość pomieszczeń wymagałaby pogłębienia posadzek, co skutkowało ogromnymi kosztami naprawy. W związku z tym Inwestor zrezygnował z dalszego jej użytkowania." - na pods. wywiadu przeprowadzonego przez autorkę z jednym z projektantów B. Szczepańskim dn. 21 lipca 2020.

19 Projekt wykonawczy nadbudowy wraz z przebudową i zmianą sposobu użytkowania budynku dawnego laboratorium E3 na budynek biblioteki Wydziału Architektury Politechniki Wrocławskiej przy ul. Chemicznej 4 we Wrocławiu, proj. Bartosz M. Żmuda, Beata Pawelec, Bartosz Dereń, Bartosz Szczepański, Wrocław, marzec 2012, ADITPwr, syg ACT/AR-E3/5, poz. 3. 
Dopełnieniem wyrazu artystycznego elewacji południowej zostały stalowe elementy takie jak klamki i kraty, wykonane według zachowanych egzemplarzy z budynku głównego.

Pozostałe elewacje zostały ukształtowane na sposób współczesny ${ }^{20}$. Od wschodu i zachodu zastosowano okładzinę z kortenu, przechodzącą płynnie w pokrycie dachowe oraz aluminiowe drzwi i okna. Zrezygnowano $\mathrm{z}$ tradycyjnego okapu i zastosowano rynnę krytąą. Elewacja północna została otynkowana $\mathrm{w}$ kolorze identycznym ze stroną południową, natomiast okna mają wyraz współczesny poprzez zastosowanie szarych, aluminiowych ram oraz szyb wielkoformatowych. Zastosowano piaskowiec identyczny z tym wykorzystanym na elewacji południowej jako opaskę dla szczytu północnego oraz cokól, ale o prostych, geometrycznych podziałach. Zlikwidowano czerpnie powietrza, usytuowane na poziomie terenu wraz z balustradami.

Zachowano ściany konstrukcyjne parteru oraz strop typu Koenen nad dawna pompownią. Dach pulpitowy powyżej dawnej hali obrabiarek zdemontowano, projektując $\mathrm{w}$ jego miejsce nową płytę żelbetową stropodachu użytkowego. Nowe ściany murowane wykonano z bloczków typu SILKA. Poddasze użytkowe, przeznaczone na czytelnię oraz dach wykonano w oparciu o stalową konstrukcję nośną. Ściany zewnętrzne, bez zachowanych, wartościowych detali historycznych, ocieplono wełną mineralną, usytuowaną pomiędzy stalową podkonstrukcją pokrycia z blachy, natomiast nowa, murowana ściana szczytowa od północy została zaizolowana styropianem.

$\mathrm{W}$ pomieszczeniach postulowano, $\mathrm{w}$ ramach możliwości, pozostawienia tynków oryginalnych, oczyszczonych ze złuszczających się powłok malarskich i zastosowanie tynków oddychających. $\mathrm{W}$ przypadku ujawnienia oryginalnej dekoracji malarskiej proponowano odsłonięcie wraz z ekspozycją lub zabezpieczenie i zasłonięcie nowymi tynkami. Wzorem dla nowoprojektowanej kolorystki wnętrz były badania korytarzy i holi budynku E1 (głównego), przeprowadzone w 2010 r. przez Agnieszkę Witkowską ${ }^{22}$. Wprowadzono nową windę towarowa, przeznaczoną do transportu książek oraz przesuwne regały magazynowe.

Przebudowy i adaptacje wiążą się z koniecznością dostosowania obiektu do obowiązujących przepisów w zakresie ochrony przeciwpożarowej, bezpieczeństwa i higieny pracy oraz dostępności dla osób niepełnosprawnych. W przypadku nowej biblioteki wydziałowej, gdzie zakres ingerencji był dość duży, wymagania mogły zostać spełnione bez konieczności stosowania odstępstw i rozwiązań zamiennych. Wejście główne zlokalizowano na poziomie terenu. Pomieszczenia przeznaczone dla osób niepełnosprawnych ulokowano na parterze budynku,

20 Wizją Projektantów było „wprowadzenie miękkiej, wyoblonej linii z blachy stalowej o wybarwieniu miedzianym - współczesną i spójną, bez odtwarzania oryginalnych tynków, okapów i czerwonej dachówki, z których zupełnie nic się nie zachowało" na pods. wywiadu przeprowadzonego przez autorkę z jednym z projektantów B. Szczepańskim dn. 21 lipca 2020.

21 Projektanci zakładali częściową perforację blachy, nie zostało to jednak zrealizowane.

22 Wyniki badań pokazały, że stolarka drzwiowa miała kolor brązowy, natomiast ściany wewnętrzne były utrzymane w odcieniach złamanej bieli, kremu złamanego różu, kremowego pomarańczu, szarości i odcieniach oliwkowych. Dokładny opis kolorystyki wnętrz znajduje się [w:] Witkowska A., Rozpoznanie konserwatorskie wybranych elementów wystroju wnętrz gmachu E1 i E5 Wydziału Architektury Politechniki Wrocławskiej, Wrocław, ul. B. Prusa 53/55, Wrocław, luty 2010, rękopis. 
eliminując tym samym konieczność instalacji dźwigu osobowego ${ }^{23}$. Wymóg wprowadzenia barierek na dachu dawnej hali obrabiarek zmienił nieco pierwotne proporcje bryły budynku od południa, jednak dzięki zastosowaniu stali kortenowej, kontrastującej z tynkiem elewacyjnym, nadal jest ona czytelna.

Obiekt ukończono w 2016 r. i od tego czasu funkcjonuje jako biblioteka uczelniana. Realizacja zdobyła również nagrodę w konkursie na najlepszą Dolnośląską Budowę Roku.

\section{Wnioski}

Adaptacja budynku dawnego laboratorium maszynowego na bibliotekę jest przykładem zindywidualizowanego podejścia do procesu projektowania. Przygotowanie koncepcji poprzedzono wykonaniem studium historycznego całości zespołu edukacyjnego dawnej Szkoły Rzemiosł Budowlanych i Wyższej Szkoły Budowy Maszyn. Wykonano badania architektoniczne, stratygraficzne tynków, wnikliwie przeanalizowano kontekst urbanistyczny, który zwykle jest pomijany, jak osie widokowe, zamknięcia perspektywy okolicznych ulic.

$\mathrm{Na}$ podstawie studiów i badań starano się określić co stanowi największą wartość w pozostałościach po dawnym obiekcie. Wnioski miały charakter zarówno urbanistyczny, jak i architektoniczno-konserwatorski. W tym przypadku zdecydowano o zachowaniu pierwotnej kompozycji kampusu Szkoły. Zrezygnowano z odtwarzania całego obiektu wraz z dawnym detalem, natomiast jego forma historyczna posłużyła jako inspiracja materialno-strukturalna ${ }^{24}$ dla formy nowoprojektowanej. Wszystkie te działania podyktowane były przyjętą filozofią harmonijnego zakomponowania zachowanych resztek budowli oraz odróżnienie części nowoprojektowanej.

Przy próbie oceny adaptacji można posiłkować się siedmioma zasadami konserwatorskimi, przytoczonymi m.in. przez Bogumiłę Roubę ${ }^{25}$ :

\section{Primum non nocere}

2. Maksymalne poszanowanie oryginalnej substancji zabytku oraz jego wartości materialnych i niematerialnych

3. Minimalna ingerencja

4. Usuwanie tego (i tylko tego), co na oryginał działa niszcząco

5. Czytelność i odróżnienie ingerencji oraz estetycznego podporządkowania oryginałowi (niekonkurencyjność)

$23 \mathrm{Na}$ poddaszu użytkowym znajduje się czytelnia wraz z tarasem użytkowym i zapleczem sanitarnym. Pomieszczenia o takiej samej funkcji znajdują się również na parterze obiektu.

${ }^{24}$ Kadłuczka A., Problemy integracji architektury wspótczesnej z historycznym środowiskiem kulturowym, Politechnika Krakowska, Kraków 1982, s. 121.

25 Rouba B., Dlaczego adaptacje niszczą zabytki i czy tak być musi? [w:] Adaptacja obiektów zabytkowych do współczesnych funkcji użytkowych, red. B. Szmygin, Wyd. Lubelskie Towarzystwo Naukowe, Międzynarodowa Rada Ochrony Zabytków ICOMOS, Politechnika Lubelska, Warszawa-Lublin 2009, s.114. 


\section{Odwracalność metod i materiałów}

7. Wykonawstwo zgodnie z najlepszą wiedzą i sztuką połączone z dokumentacją wyników badań i przebiegu kolejnych działań.

W przypadku budynku dawnego laboratorium maszynowego najwięcej szkody, obok II wojny światowej, przyniosła adaptacja z lat 60. XX w., przeprowadzona bez studiów nad wartością historyczną obiektu. Ostatnie działania miały na celu odsłonięcie, konserwację i ekspozycję zachowanych reliktów budowli, reintegrację elewacji południowej oraz rekonstrukcję (w uproszczonym kształcie) sylwety wieży wodnej. Zadbano o czytelność elementów dodanych współcześnie i tych zachowanych, należy jednak zaznaczyć, że ze względu na stosunkowo niewielką część murów pierwotnych, zakres ingerencji był dość duży.

W przypadku adaptacji obiektów zabytkowych do współczesnych potrzeb mamy do czynienia nie tylko ze złożoną problematyką konserwatorską, ale również z zagadnieniami dotyczącymi ochrony przeciwpożarowej, wymagań sanitarnych oraz dostosowania obiektu dla osób niepełnosprawnych. Chcąc utrzymać zasadę minimalnej ingerencji należy strategicznie zaprojektować funkcje pomieszczeń, tak aby zabiegi adaptacyjne ograniczyć do niezbędnego minimum. W przypadku dawnego laboratorium zrezygnowano z pomieszczeń przeznaczonych do przebywania powyżej 50 osób, co umożliwiło m.in. obniżenie wymagań odnośnie odporności ogniowej przegród budowlanych. Obiekty zabytkowe, o stosunkowo niewielkich rozmiarach, w których z różnych względów niemożliwe jest zaprojektowanie pochylni lub budowa dźwigu osobowego, powinny posiadać pomieszczenia dostosowane dla osób niepełnosprawnych na parterze.

Największym wyzwaniem projektowym dla architektów stanowiło zmieszczenie całego, założonego programu użytkowego w obrysie ocalałej części budynku². Zakres opracowania został narzucony projektantom przez Inwestora jeszcze na etapie opracowań koncepcyjnych. Można było rozważyć rozszerzenie zakresu i przywrócenie nieistniejącej hali maszyn w dawnym gabarycie. Takie rozwiązanie z pewnością byłoby korzystne, gdyż potrzeby funkcjonalne biblioteki są większe. Architekci starali się wykorzystać przestrzeń w jak najbardziej ekonomiczny sposób poprzez umieszczenie urządzeń technicznych wentylatorowni w bryle odtwarzanej wieży, wydzielenie toalety dla niepełnosprawnych pod schodami, wykorzystanie tarasu na zewnętrzną czytelnię w okresie wiosennym i letnim. Niemniej nawet projektanci przyznają, że „biblioteka powinna być większa”27.

${ }^{26}$ Na pods. wywiadu przeprowadzonego prze autorkę z jednym z projektantów B. Szczepańskim dn. 21 lipca 2020.

27 Na pods. wywiadu przeprowadzonego prze autorkę z jednym z projektantów B. Szczepańskim dn. 21 lipca 2020. 
Ważnym zagadnieniem jest rozwiązanie problemu termoizolacyjności przegród budowlanych. Wprawdzie obiekty zabytkowe nie muszą spełniać norm analogicznych z nowymi realizacjami, natomiast całkowite pominięcie tego zagadnienia wpływa na komfort użytkowania obiektu i może prowadzić do samowoli budowlanych. Należy rozważnie projektować sposób wprowadzania nowoczesnych instalacji w obiektach zabytkowych, tak aby w miarę możliwości nie naruszać ich struktury.

Dialog pomiędzy dawną formą a współczesnymi potrzebami z pewnością może zakończyć się porozumieniem, łączącym potrzeby obu stron. Jednak aby tak się stało, konieczne jest wykonanie badań i studiów historycznych w ramach prac przedprojektowych. Obowiązek wykonywania takich opracowań powinien znaleźć odzwierciedlenie w obowiązujących przepisach prawa.

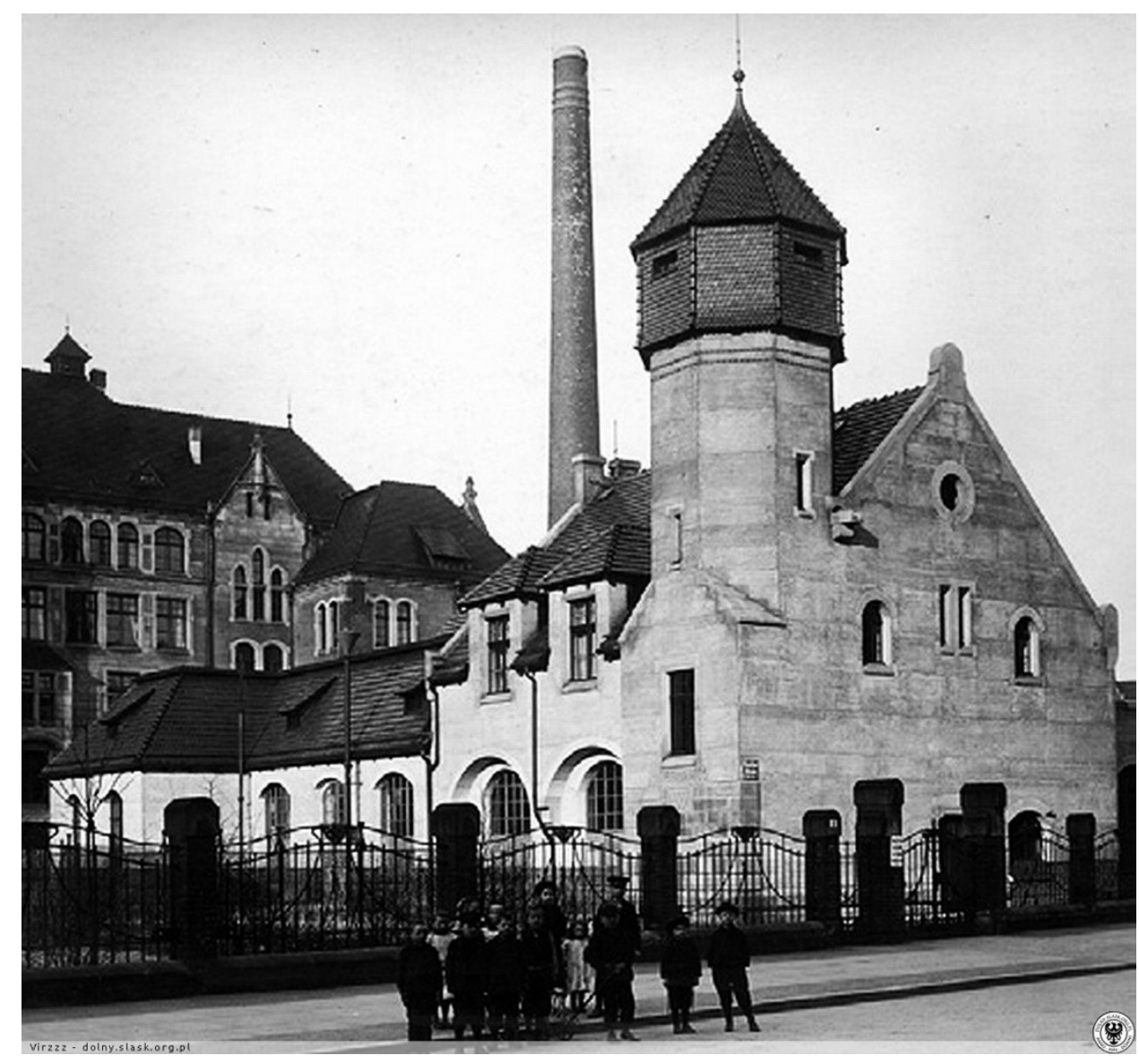

Ryc. 1 Budynek dawnego laboratorium maszyn, stan w 1907 r., źródło: Biblioteka Uniwersytecka na Piasku we Wrocławiu, Oddział Zbiorów Graficznych, sygn. 818, dostęp z portalu https://polska-org. $\mathrm{pl} /[10.12 .2018]$ 


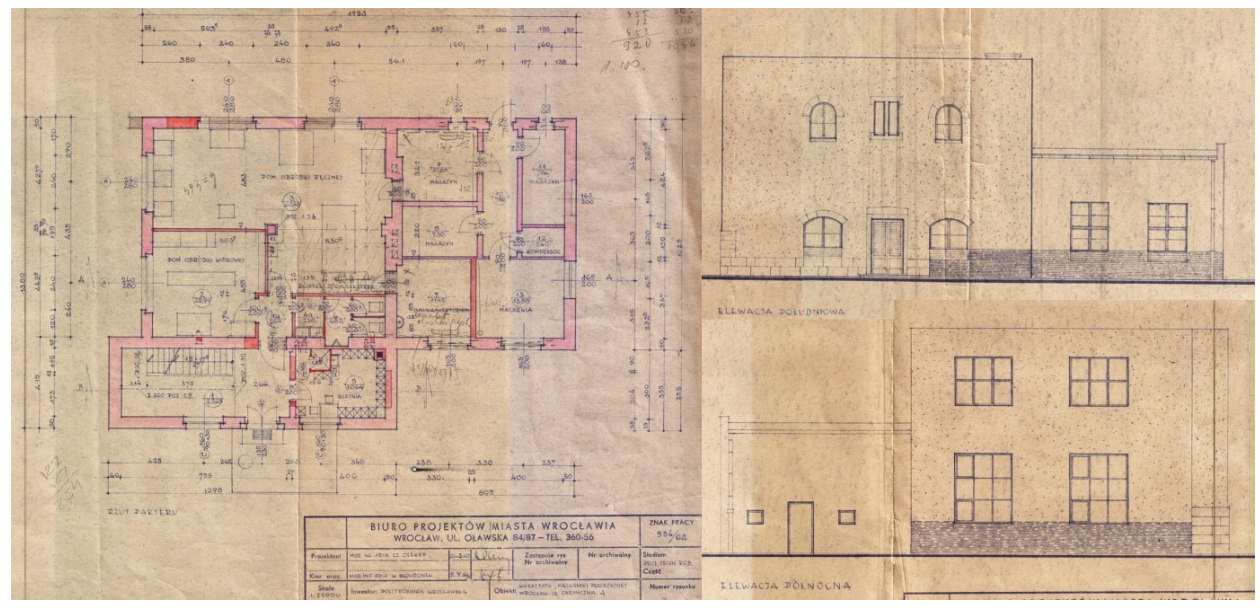

Ryc. 2 Projekt adaptacji i przebudowy dawnego laboratorium maszynowego z 1963 r. na warsztat mechaniki precyzyjnej dla Politechniki Wrocławskiej, źródło: Archiwum Działu Infrastruktury Technicznej Pwr (ADITPwr), syg ACT/AR-E3/1, poz. 1, 3
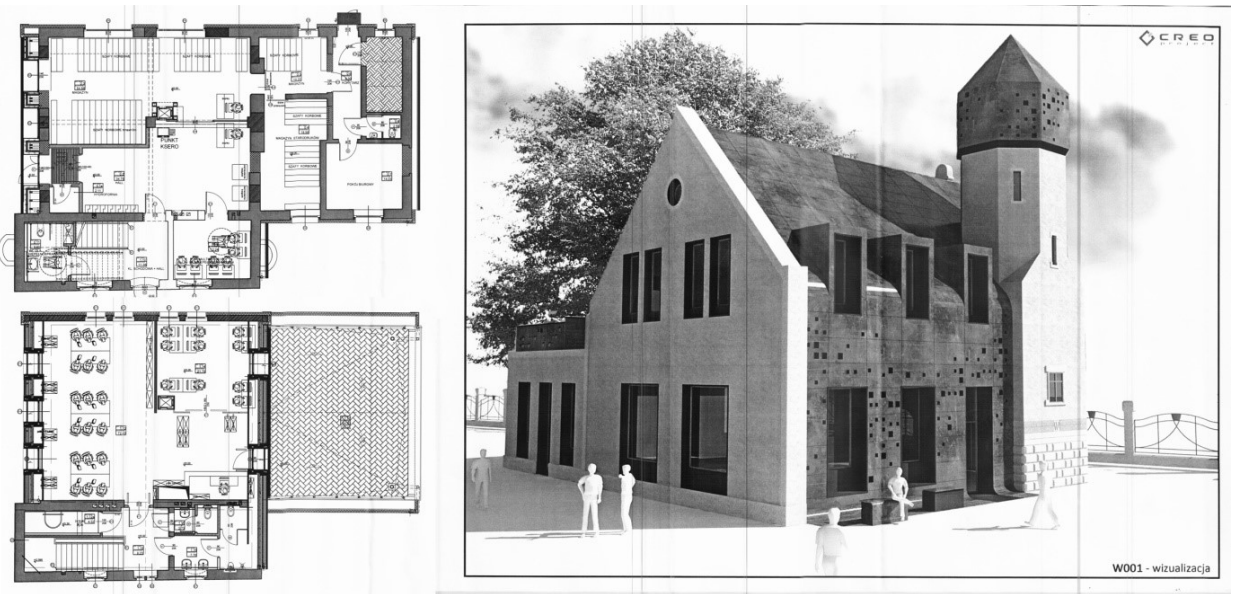

Ryc. 3 Projekt koncepcyjny przebudowy i adaptacji dawnego laboratorium maszynowego na bibliotekę dla Wydziału Architektury Politechniki Wrocławskiej, Creoprojekt, 2011, źródło: ADITPwr, syg ACT/AR-E3/5, poz. 1 


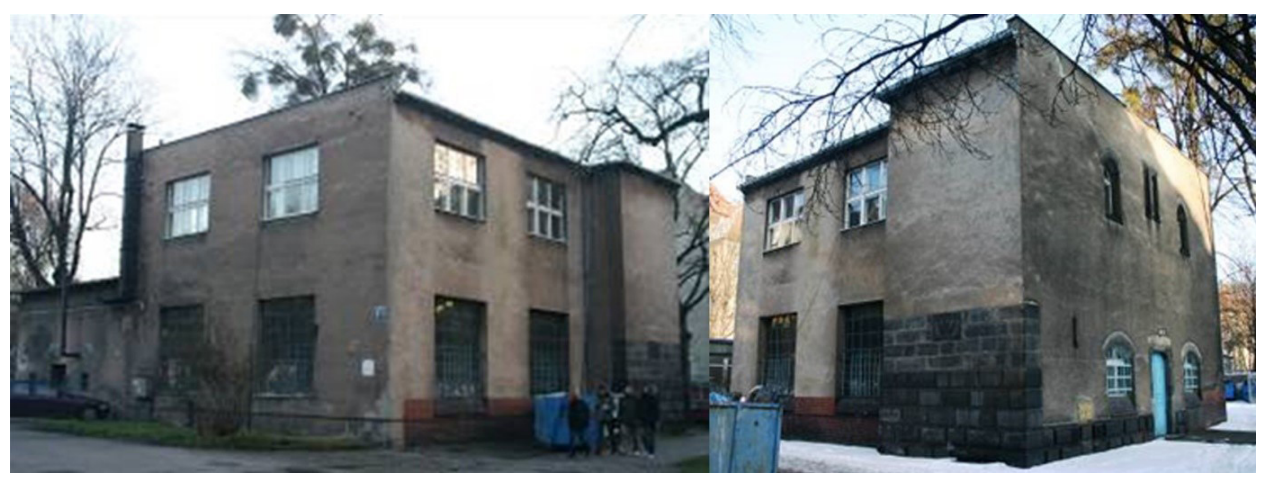

Ryc. 4 Budynek dawnego laboratorium maszynowego, stan przed przystąpieniem do prac w 2009r., fot. A. Grylewska, źródło: Gryglewska A., Brzezowski W., Studium historyczne $z$ wnioskami konserwatorskimi kompleksu dawnej Baugewerk und Maschinenbauschule, obecnie budynków Politechniki Wrocławskiej przy ul. B. Prusa 53/55 we Wrocławiu, Sprawozdanie z serii nr 029/09, rękopis, Wrocław 2009

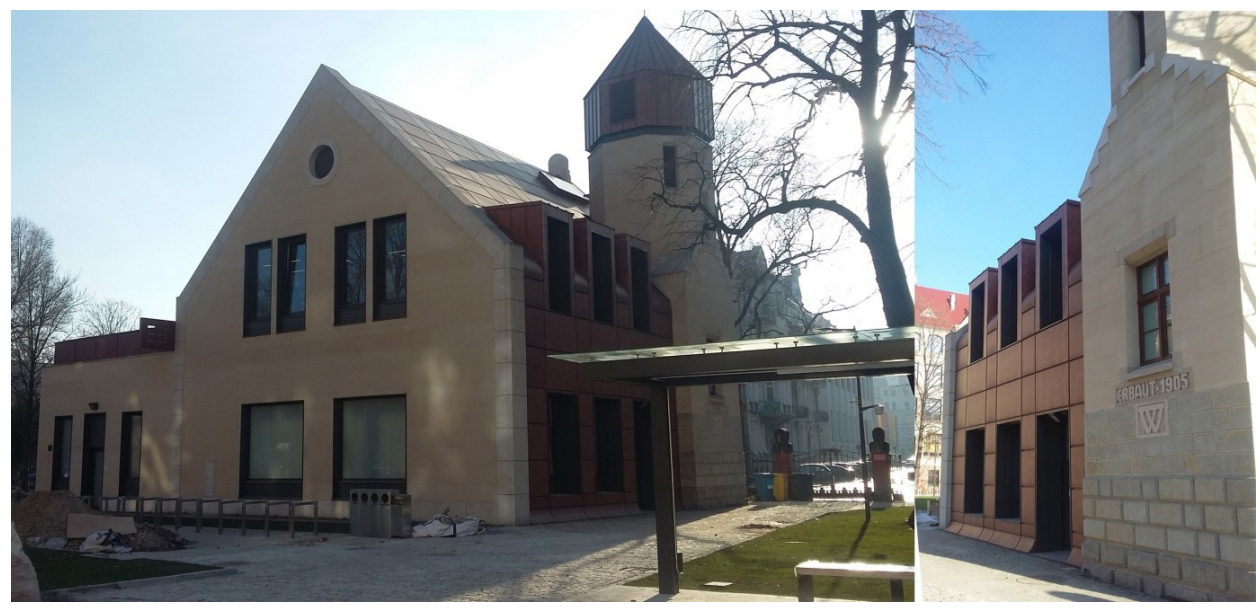

Ryc. 5 Budynek po przebudowie i adaptacji na bibliotekę Wydziału Architektury Politechniki Wrocławskiej, grudzień 2018, fot. E. Grodzka 


\section{Bibliografia}

Gryglewska A., Architektura Wrocławia XIX-XX wieku w twórczości Richarda Plüddemanna, Oficyna Wydawnicza Politechniki Wrocławskiej, Wrocław 1999.

Gryglewska A., Brzezowski W., Studium historyczne z wnioskami konserwatorskimi kompleksu dawnej Baugewerk und Maschinenbauschule, obecnie budynków Politechniki Wrocławskiej przy ul. B. Prusa 53/55 we Wrocławiu, Sprawozdanie z serii nr 029/09, rękopis, Wrocław 2009.

Gryglewska A., Gmach dawnej Szkoły Rzemiost Budowlanych - siedziba Wydziału Architektury Politechniki Wrocławskiej. Idea projektu [w:] Schola Architecturae Budynki Szkół Architektury, red. O. Czerner, A. Gryglewska, Oficyna Wydawnicza Politechniki Wrocławskiej, Wrocław 2005, s. 75-92.

Kadłuczka A., Problemy integracji architektury wspótczesnej $z$ historycznym środowiskiem kulturowym, Politechnika Krakowska, Kraków 1982.

Rouba B., Dlaczego adaptacje niszcza zabytki i czy tak być musi? [w:] Adaptacja obiektów zabytkowych do współczesnych funkcji użytkowych, red. B. Szmygin, Wyd. Lubelskie Towarzystwo Naukowe, Międzynarodowa Rada Ochrony Zabytków ICOMOS, Politechnika Lubelska, Warszawa-Lublin 2009, s. 113-128.

\section{Materiały archiwalne}

Projekt zagospodarowania terenu z 1902 r., Archiwum Budowlane m. Wrocławia, syg. 2159.

Projekt techniczno-roboczy - warsztat mechaniki precyzyjnej, proj. Czesław Oleksy, ul. Chemiczna 4, Wrocław 1963, Archiwum Działu Infrastruktury Technicznej Pwr (ADITPwr), syg ACT/AR-E3/1, poz. 1, 3.

Projekt wykonawczy nadbudowy wraz z przebudową i zmianą sposobu użytkowania budynku dawnego laboratorium E3 na budynek biblioteki Wydziału Architektury Politechniki Wrockawskiej przy ul. Chemicznej 4 we Wrockawiu, proj. Bartosz M. Żmuda, Beata Pawelec, Bartosz Dereń, Bartosz Szczepański, Wrocław, marzec 2012, ADITPwr, syg ACT/AR-E3/5, poz. 3.

Protokół nr 14/78 z posiedzenia Rady Naukowo-Technicznej z dn. 21.06.1978 w Zakładzie Studyjno-Projektowym Politechniki Wrocławskiej, ADITPwr, syg ACT/AR-E3/2, poz. 2.

\section{Pozostałe}

https://www.facebook.com/biurocreoproject [dostęp: 29.01.2019].

wywiad przeprowadzony przez autorkę z jednym z projektantów B. Szczepańskim dn. 21 lipca 2020. 